\title{
The role of habitat heterogeneity in structuring the community of intertidal free-living marine nematodes
}

\author{
Ruth Gingold • Manuel Mundo-Ocampo • \\ Oleksandr Holovachov $•$ Axayácatl Rocha-Olivares
}

Received: 15 October 2009 / Accepted: 7 April 2010 / Published online: 27 April 2010

(C) The Author(s) 2010. This article is published with open access at Springerlink.com

\begin{abstract}
The role of habitat complexity has been widely neglected in the study of meiofaunal community patterns. We studied the intertidal nematode community of a structurally complex macrotidal beach exhibiting contrasting microhabitats (sandbars and runnels) to understand the influence of environmental gradients and habitat heterogeneity in the community structure. We tested whether topographical complexity affected (1) the zonation pattern in terms of abundance and diversity, and (2) local diversity by promoting compartmentalization into distinct faunal groups. Our analyses revealed three major faunal assemblages along the exposure gradient associated to differences in mean grain size and chlorophyll $a$. Diversity patterns involved a mid-intertidal peak, consistent with the intermediate disturbance hypothesis, and another peak at the limit with the subtidal region, consistent with the transition zone. These results highlight the predominance of environmental gradients in establishing intertidal zonation. However,
\end{abstract}

Communicated by M. Kühl.

Electronic supplementary material The online version of this article (doi:10.1007/s00227-010-1447-z) contains supplementary material, which is available to authorized users.

R. Gingold $(\varangle) \cdot$ A. Rocha-Olivares $(\square)$

Department of Biological Oceanography,

Centro de Investigación Científica y de Educación Superior

de Ensenada, Carretera Ensenada-Tijuana 3918,

Apdo. Postal 2732, 22860 Ensenada, Baja California, Mexico

e-mail: rgingold@cicese.mx

A. Rocha-Olivares

e-mail: arocha@cicese.mx

M. Mundo-Ocampo $\cdot$ O. Holovachov

Department of Nematology, University of California,

Riverside, CA 92521-0415, USA microhabitats differed in environmental conditions and possessed significantly distinct nematofaunal communities. Runnels featured higher levels of taxonomic and functional diversity, many unique genera, and the community differed from the assemblage at the limit to the subtidal, stressing their role as distinct microhabitats. The nematofauna of the structurally complex beach was more diverse than the one from a homogeneous beach nearby, supporting the hypothesis that structural heterogeneity promotes diversity by compartmentalization and highlighting the importance of microhabitats in the assessment of biodiversity. Contrary to previous predictions, our results indicate potentially high regional marine nematode diversity in the Upper Gulf of California.

\section{Introduction}

The intermediate disturbance hypothesis (IDH), the dynamic equilibrium hypothesis (DEH), and the habitat heterogeneity hypothesis $(\mathrm{HHH})$, are building blocks of modern community ecology and relate ecological processes to the generation and maintenance of diversity and community functioning. The IDH posits that species diversity will be maximal in habitats subject to intermediate levels of disturbance because stochastic, intermediate (partial) elimination of resources by disturbance leads to species-specific mortality allowing the co-existence of competitively inferior species (Huston 1979). Moreover, according to the $\mathrm{DEH}$, the combination of intermediate disturbance with intermediate productivity levels, predicts a peak in species richness due not only to periodic decreases of competitively dominant species but also to increased niche packing (Huston 1994). Finally, the HHH states that structurally complex environments provide more niches thereby 
increasing species diversity (MacArthur and Wilson 1967). The majority of empirical studies find increased diversity at intermediate disturbance (Aronson and Precht 1995; Flöder and Sommer 1999; but see Huxham et al. 2000) and a positive relationship between habitat complexity and species diversity (Davidowitz and Rosenzweig 1998; French and Picozzi 2002; Hendrickx et al. 2007; Kerr and Packer 1997; Tews et al. 2004; but see Cramer and Willig 2005).

Intertidal sandy beaches may appear homogeneous, but horizontal and vertical physical, chemical, and biological gradients create a spatially and temporally heterogeneous environment for the inhabiting fauna (Rodil et al. 2006). Swash and surf processes, tidal exposure (submergence) as well as related chemical gradients dominate the environmentally extreme upper and lower beaches, respectively, whereas the combination of those factors creates an environment of intermediate disturbance in the mid-intertidal (McLachlan and Brown 2006). Whereas species richness and abundance tend to increase toward the lower intertidal in macrofauna (i.e. organisms retained by a sieve of $1 \mathrm{~mm}$ pore size), since their feeding activity is directly dependent on tidal submergence (Armonies and Reise 2000; McLachlan and Jaramillo 1995), meiofauna (i.e. organisms passing through a $1-\mathrm{mm}$ mesh and retained by a $0.04-\mathrm{mm}$ mesh) exhibit a peak in species richness around the mid-intertidal. Meiofauna is usually dominated by the highly diverse freeliving marine nematodes (Lambshead 1993), and is more likely to respond to the three-dimensional complex interaction between chemical, physical, and biological factors rather than to any single factor or process alone (Rodriguez et al. 2001). Cross-shore meiofaunal distribution patterns consist in species assemblages corresponding to different intertidal levels (Gheskiere et al. 2004, 2005; Rodriguez 2004). Although diversity patterns do not always parallel abundance, both tend to increase with increasing distance from the waterline, often with a peak around the mid-intertidal (Armonies and Reise 2000; Gheskiere et al. 2004; Rodriguez et al. 2001). The mid-intertidal maxima in species richness have been attributed to optimal combinations of physical and chemical conditions (Armonies and Reise 2000; Gheskiere et al. 2004).

Environmental gradients as well as individual environmental factors have received foremost attention in our understanding of intertidal community patterns, whereas the role of habitat complexity has been widely neglected or even avoided (Gheskiere et al. 2004; Mundo-Ocampo et al. 2007). However, complexity is the hallmark of some beach types, such as macrotidal (i.e. tide governed) or intermediate beaches featuring tidal sandbars and runnels providing additional temporal and spatial heterogeneity. On dissipative macrotidal ridge-and-runnel beaches (sensu Masselink and Short 1993), such as the one studied here, several intertidal bar systems are located parallel to the shoreline
(Masselink et al. 2006). Runnels are less exposed than the intervening sandbars, since they remain partially submerged during low tide and partly protected against crossshore currents. Consequently, environmental factors such as humidity, temperature, sediment characteristics, and organic matter content may differ considerably between runnels and sandbars. As a result, morphodynamically complex beaches have been hypothesized to harbor higher species diversity than other beach types (McLachlan and Turner 1994). The role of local structural complexity in determining meiofaunal community structure, in general, and of tidal sandbars and runnels, in particular, remains unexplored.

In this study, we test relevant hypotheses about the role of environmental gradients and habitat heterogeneity in the community structure of meiobenthic marine nematodes. First, we tested whether the topographical complexity of a beach affects the general community structure in terms of zonation and abundance/diversity patterns. In particular, we predict that (1) the prevalent tidal regime exerts a major influence on the community, leading to distinct faunal assemblages associated to their tidal level, and (2) diversity patterns are consistent with the IDH and DEH, exhibiting a peak in diversity around the mid-intertidal level. Second, we address for the first time the issue of whether beach structural complexity leads to higher nematofaunal diversity. In particular, we predict that (3) runnels and sandbars feature distinct environmental conditions and function as microhabitats harboring distinct communities, and (4) in accordance with the $\mathrm{HHH}$, a morphologically heterogeneous beach will harbor a more diverse fauna than a structurally less complex beach.

\section{Materials and methods}

Study site and sampling design

El Tornillal beach is a pristine beach located far from direct urban sewage outfalls or industrial and agricultural runoff in the northern Gulf of California in the Biosphere Reserve of the Upper Gulf of California (UGC) and Colorado River Delta $\left(31^{\circ} 33^{\prime} \mathrm{N}, 114^{\circ} 17^{\prime} \mathrm{W}\right.$; Fig. 1). The Gulf of California is a marine biodiversity hotspot worldwide and one of the greatest reservoirs of marine species (Enríquez-Andrade et al. 2005). Morphodynamically, El Tornillal is a dissipative macrotidal ridge-and-runnel beach (sensu Masselink and Short 1993), featuring an intertidal area $>600-\mathrm{m}$ wide and a tidal range reaching $7 \mathrm{~m}$ during spring tides (Lluch-Cota et al. 2007). Intertidal runnels are oriented almost parallel to the water line retaining seawater during low tide. The temporal and spatial dynamics of sandbars and runnels have not been studied in the Gulf of California. 


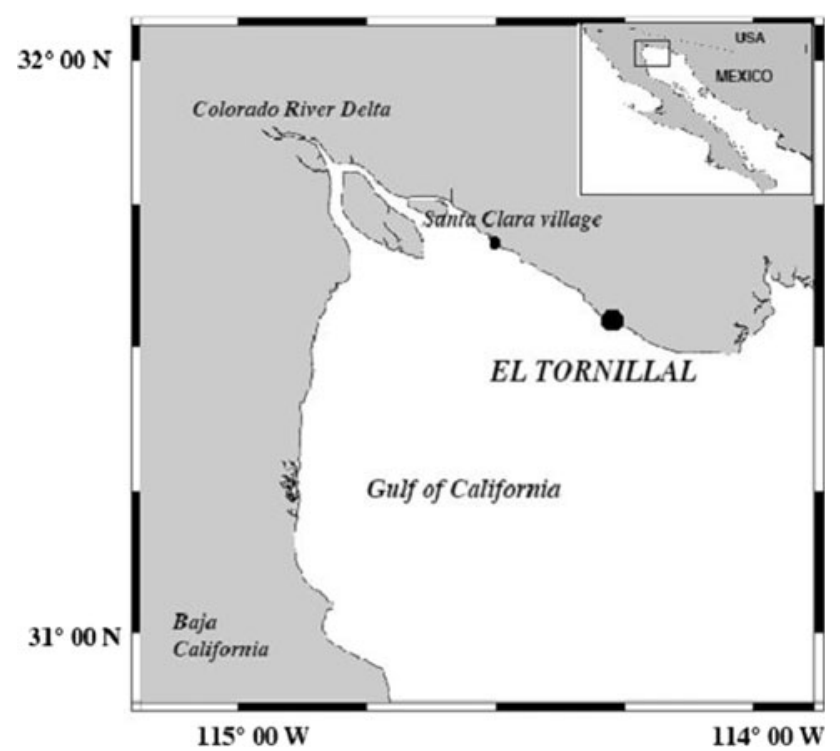

Fig. 1 Location of the study site (El Tornillal beach) on the east coast of the Upper Gulf of California, state of Sonora, Mexico

However, in topographically similar beaches in northern Europe, sandbars tend to remain stationary across shore for up to 17 months (King 1972), whereas longshore currents as well as tidal and wave action cause longshore migration of medium-sized bedforms $(<100 \mathrm{~m})$ due to advection and re-suspension of sand (Anthony et al. 2005). Sea surface temperatures are $30-32^{\circ} \mathrm{C}$ from June to September and range from 16 to $18^{\circ} \mathrm{C}$ from November to April. Southeastern currents and relatively low productivity prevail during summer and the pattern reverses with northwestern currents and high productivity during winter (Lluch-Cota et al. 2007). No macroalgal wrack deposits are found across the beach.

Sampling took place in contrasting seasons: September (27/09/07) and March (08/03/08), during the highest spring tide of the month. For each season, ten stations were placed along a transect perpendicular to the shore ranging from the waterline (station 1) to the high tide mark (station 10). Stations were placed such that they alternated runnels (oddnumbered) and sandbars (even-numbered; Fig. 2a). The locations of sampling stations between seasons were at most $100 \mathrm{~m}$ away from each other, as indicated by their GPS position. At each station, sediment cores were taken at random within a $1 \mathrm{~m}^{2}$ area using a PVC corer. Triplicate samples were taken for each of the following analyses (1) meiofauna, (2) granulometry, (3) organic matter, and (4) microphytobenthos. Core size for meiofauna, granulometry and organic matter was $9.8-\mathrm{cm}$ long by $2.9 \mathrm{~cm}$ in diameter, and for microphytobenthos $1-\mathrm{cm}$ long by $1 \mathrm{~cm}$ in diameter. Samples for meiofaunal analyses were fixed immediately in $5 \%$ formaldehyde. Organic matter samples were kept under ice in the field, and then frozen at $-20^{\circ} \mathrm{C}$ until processed.
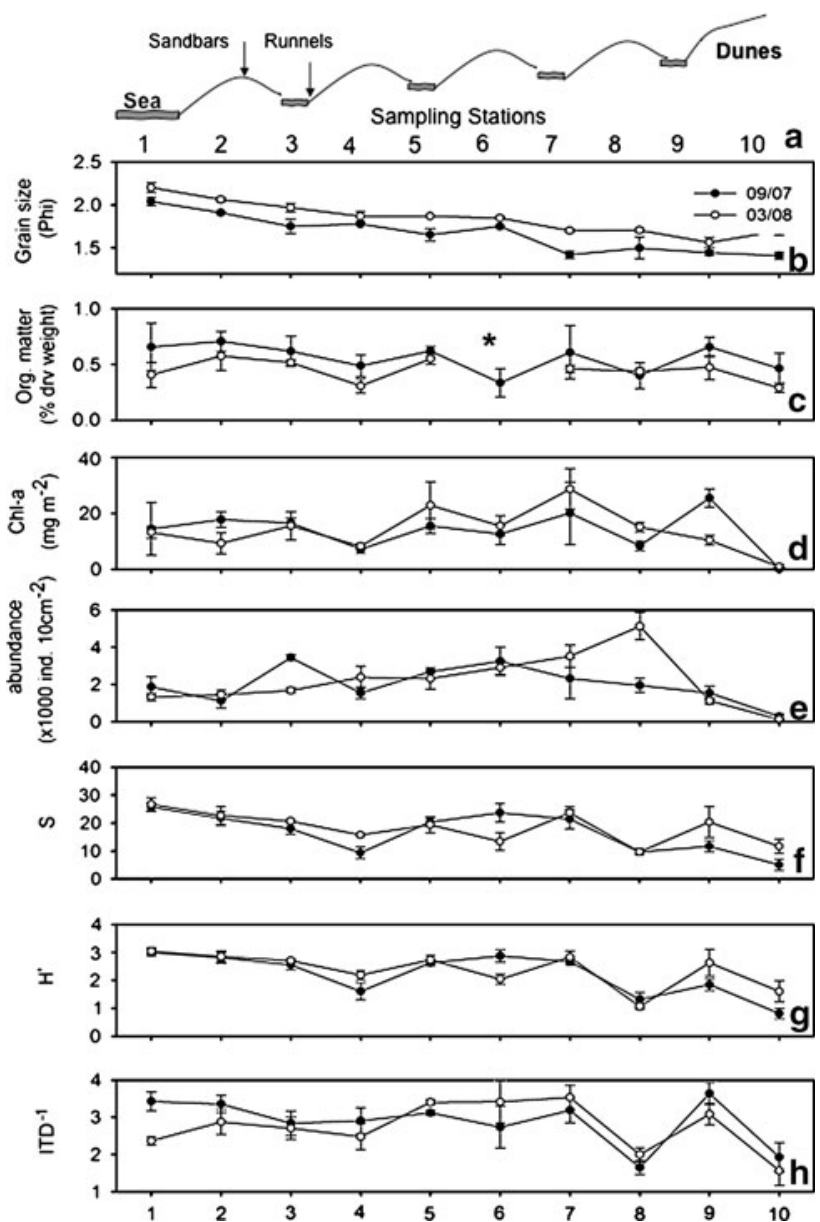

Fig. 2 Environmental and biological variables across the intertidal in September 2007 (black circles) and March 2008 (open circles). a Schematic illustration of stations along a transect; means and standard deviations of b mean grain size (in $\Phi$ ); $\mathbf{c}$ organic matter content (\% dry weight); d chlorophyll $a$ density $\left(\mathrm{mgm}^{-2}\right)$; e nematode abundances (individuals $10 \mathrm{~cm}^{-2}$ ); $\mathbf{f}$ genus richness $(S)$; $\mathbf{g}$ taxonomic diversity (Shannon Wiener $H^{\prime}$ ) and $\mathbf{h}$ trophic diversity $\left(\mathrm{ITD}^{-1}\right)$. Asterisks denote missing data

Chlorophyll samples were kept in dark tubes under ice in the field, and then stored at $-40^{\circ} \mathrm{C}$ until processed.

Faunal analyses

In the laboratory, formalin was rinsed off sediment samples with freshwater using a $45-\mu \mathrm{m}$ sieve. Bulk extractions of meiofauna from the sediment cores involved suspension in colloidal silica (LUDOXTM, specific density 1.15 ) following De Jonge and Bouwman (1977). Extracted organisms were stored in $5 \%$ formalin and five aliquots of $5 \mathrm{ml}(25 \mathrm{ml}$ in total per sample) were used to quantify nematodes using a counting dish under a Leica Zoom 2000 stereoscope. Nematode density (ind $10 \mathrm{~cm}^{-2}$ ) in each core was calculated by the mean abundance of the five aliquots and extrapolated to total abundance based on the fraction of the volume of each aliquot relative to that of the fixed bulk 
extraction, which varied between 25 and 35\%. Aliquots were transferred to a $5 \%$ glycerol solution and slowly evaporated on a heating plate. The first 50 randomly picked nematodes were mounted on permanent slides for identification. Nematodes were identified to the generic level when possible, using both pictorial (Platt and Warwick 1983, 1988; Warwick et al. 1998) and online (http://nemamex. ucr.edu) taxonomic keys with an OLYMPUS BX51 compound microscope with differential interference contrast optics. In cases where generic identification was not possible (e.g., for juveniles or females lacking unequivocal male counterparts) specimens were identified to family level and included in statistical analyses as such. If more than one species could be distinguished among congeners, they were labeled sp $1, \mathrm{sp} 2$, and treated separately in statistical analyses, except in calculations of genus richness.

\section{Habitat characterization}

Granulometric analyses included first treating samples with $30 \%$ peroxide $\left(\mathrm{H}_{2} \mathrm{O}_{2}\right)$ to oxidize organic matter. After rinsing gently with distilled water and drying at $60^{\circ} \mathrm{C}$ they were sieved through a stack of Wentworth grade sieves and the dry weight of each fraction was obtained (Bale and Kenny 2005). Mean grain size was calculated as $\Phi\left(-\log _{2}\right.$ [grain diameter]) with the program SysGran 2.4. Organic matter content was determined after treating samples with $10 \%$ $\mathrm{HCl}$ to dissolve inorganic carbonates (mainly $\mathrm{CaCO}_{3}$ ), rinsing them thoroughly with fresh water, freeze-drying and then combusting them at $550^{\circ} \mathrm{C}$ for $24 \mathrm{~h}$ (Dean 1974; Froelich 1980). Organic matter was computed as the difference in dry weight before and after combustion and standardized to percentage of total dry weight before combustion. Phytobenthic chlorophyll was extracted by grinding sediment samples in $90 \%$ acetone, extracting for $24 \mathrm{~h}$ in the dark and then centrifuging at 3,000 rpm for $10 \mathrm{~min}$. Absorbance of the supernatant was measured at 665 and $750 \mathrm{~nm}$ before and after acidification with a few drops of $10 \% \mathrm{HCl}$ (Spectrophotometer Ely-2000, Elyptica, Ensenada, BC, Mexico). Chlorophyll density was calculated following Lorenzen (1967) and Colijn and Dijkema (1981) and expressed as $\mathrm{mg} \mathrm{m}^{-2}$.

\section{Data analyses}

To understand the faunal and environmental spatial structure across the intertidal zone (i.e. the grouping of similar samples), cluster analysis and non-metric multidimensional scaling (MDS) were applied to similarity and distance matrices. Faunal analyses were carried out with Bray-Curtis similarity matrices (Clarke and Warwick 1994). Environmental analyses were based on Euclidean distances after normalization (x-mean/SD). Clusters were constructed using a hierarchical agglomerative method with group average linkage (Clarke and Warwick 1994). Similarity profiles were used a posteriori to determine the statistical significance of each split in the dendrogram using a permutation technique under the null hypothesis of no inherent structure among samples (Clarke et al. 2008).

To assess the relationships between multivariate environmental (i.e. mean grain size, organic matter and chlorophyll density) and biotic (i.e. genus abundance) data, we used RELATE analysis, which conducts a Spearman's ranked correlation between the two similarity matrices (biotic and abiotic). To determine if environmental variables changed gradually across shore, we correlated them with station numbers, as a proxy for position along the intertidal. To evaluate which environmental variables were defining community structure in different regions of the intertidal, we used the linkage tree (LINKTREE) routine, which maximizes the $R$ statistic at each split of the community matrix in concordance with differences in underlying environmental parameters (Clarke et al. 2008; Clarke and Warwick 1994).

To explore abundance and community structure in terms of taxonomic and functional diversity we calculated the genus richness $(S)$, Shannon Wiener $\left(H^{\prime}\right)$ index and the Index of Trophic Diversity (presented as ITD ${ }^{-1}$ henceforth) modified from Heip et al. (1985), applying the formula $1 / \Sigma \theta^{2}$, where $\theta$ is the fraction of each of the four functional groups. It ranges from 1 (when one functional group contributes $100 \%$ and functional diversity is lowest) to 4 (when each functional group contributes $25 \%$ and functional diversity is highest). The ITD is based on Wieser's (1953) classification. Nematode genera are grouped into four feeding types: 1A Selective deposit and bacteria feeders with unarmed, small buccal cavity, 1B non-selective deposit feeders with unarmed wide buccal cavity, 2A Epistratum feeders, herbivorous and bacterivorous species with lightly armed small buccal cavity, and 2B carnivores and omnivores with wide armed buccal cavities.

To test for differences in abundance as well as taxonomic and functional diversity between runnels and sandbars, student's $t$ tests were performed after verifying homoscedasticity with Bartlett's test (Sokal and Rohlf 1995). If the data exhibited heteroscedasticity, Welch's approximate $t$ tests were performed (Zar 1984). Analyses of similarites (ANOSIM) were applied to multivariate data. ANOSIM is conceptually comparable to ANOVA, yet makes no assumptions about the data distribution. The test statistic $R$ equals 1 if all replicates within groups are more similar to each other than to any replicate from different groups and is approximately 0 if similarities within and among groups are the same on average. In order to determine which genera and functional groups contributed most to the similarity within each assemblage, we performed similarity percentage analyses (SIMPER). 
To compare the potential local genus richness at El Tornillal with a comparable beach studied near Santa Clara, $25 \mathrm{~km}$ further north by Mundo-Ocampo et al. (2007), we estimated total genus richness at El Tornillal by plotting a species accumulation curve (SAC) and computing nonparametric genus richness estimators. The SAC was constructed by plotting the cumulative number of genera against number of samples applying the Ugland index (Ugland et al. 2003) with the program EstimateS (Colwell 2005). The Morgan-Mercer-Flodin (MMF) Model $y=\left(a b+c x^{d}\right) /\left(b+x^{d}\right)$ was fitted to the SAC (Morgan et al. 1975) using the software Curve Expert (http://curveexpert.webhop.net). The estimated maximum genus richness is represented by the asymptote (parameter $c$ ) of the model. As a complementary method, we computed non-parametric genus richness estimators. Among all possible estimators, we chose the Incidence-Based Coverage Estimator (ICE, Chazdon et al. 1998), which allowed a direct comparison with the study by Mundo-Ocampo et al. (2007). The Second-Order Jackknife Estimator (Jack2, Burnham and Overton 1979) was also chosen as it yielded the best estimation compared to the SAC. The ICE is based on the proportion of infrequent genera that are not unique, whereas the Jack2 is based on the frequency of unique and duplicate genera. To assess the estimation error associated with our sampling effort, we calculated the estimation error of Jack2 using the equation $y=100-(A / E) \times 100$, where $y$ is the estimation error (in percent), $A$ is the asymptote of the SAC (parameter $c$ of the MMF Model) and $E$ is the estimated genus richness by the Jack 2 estimator (Canning-Clode et al. 2008). To calculate the number of samples at which the error associated with the estimation of taxonomic richness would be 0 or $<5 \%$, we fitted different models to the plot of the relative estimation error against number of samples (CanningClode et al. 2008).

Multivariate analyses were conducted with the program PRIMER version 6 (Clarke and Gorley 2001; Clarke and Warwick 1994). Univariate analyses were performed with the program STATISTICA (Statsoft 2005).

\section{Results}

\section{Zonation patterns}

Even tough the same five dominant families (Epsilonematidae, Xyalidae, Desmodoridae, Cyatholaimidae, Chromadoridae) accounted for $>75 \%$ of nematodes in both seasons, faunal groups differed slightly but significantly (ANOSIM, $R=0.099, p=0.004$ ), therefore subsequent analyses were conducted separately.

The nematode community structure at El Tornillal was spatially heterogeneous across the intertidal and featured distinct species assemblages. Cluster analyses revealed at least three major groups $(p<0.05)$ at a level of $18.26 \%$ similarity in September 2007 and $18.25 \%$ similarity in March 2008 (Fig. 3a). In September 2007, groups clearly matched sample position in the intertidal: lower (stations 13), middle (stations 4-9), and high beach (station 10; Fig. 3a). In March 2008, the pattern recurred, except that stations 5 and 7 (both runnels) clustered with stations 1-3 (Fig. 3a). MDS plots revealed the same groups with low stress values (September 2007: 0.1; March 2008: 0.12; Fig. 3b).

Unlike nematodes, environmental variables were not spatially clustered. Instead, the position of replicate samples in MDS plots suggested the presence of an environmental gradient (stress values September 2007: 0.14; March 2008: 0.08; Fig. 3c), corroborated by the significant correlation of environmental variables with station number, as a proxy of position in the intertidal (RELATE September 2007: $\rho=0.472, p=0.001$; March 2008: $\rho=0.515, p=0.001)$.

Transitions between intertidal faunal groups were consistently associated with shifts in environmental conditions in both seasons. In September, the high beach community (station 10) was set apart from the rest due to very low to zero chlorophyll $a$ values (LINKTREE September 2007: $R=0.97, B \%=99)$. Further grouping led to a division into two main groups differentiated by mean grain size: stations 1, 2 and one replicate of station 3 versus the rest of replicates from stations 3-9 $(R=0.63, B \%=63)$. In March, the pattern was similar but ranked differently: One replicate of station 10 was set apart due to a zero chlorophyll $a$ value $(R=0.58$, $B \%=80)$. The next division was due to mean grain size and separated stations $1-3$ from the rest $(R=0.64, B \%=67)$. Finally, the two remaining station 10 replicates were set apart from stations 4 to 9 due to lower chlorophyll $a$ values $(R=0.65, B \%=61)$. These results stress the significance of chlorophyll levels in structuring the faunal assemblages in the high intertidal and of mean grain size in the middle and lower beach, which is also consistent with the gradual trend of increasing grain size (i.e. decreasing $\Phi$ values) with increasing distance from the sea (Fig. 2b).

Local abundance and diversity patterns

The mean density of nematodes over the entire intertidal was strikingly similar between contrasting seasons (September $20072,001 \pm 1,007 \mathrm{SD}$ individuals $10 \mathrm{~cm}^{-2}$, March 2008 2,194 $\pm 1,407)$. In September, there was no discernible spatial pattern, with highest abundance $(3,445$ ind. $10 \mathrm{~cm}^{-2}$ ) at station 3 , and a second peak at station 6 (3,247 ind. $10 \mathrm{~cm}^{-2}$; Fig. 2e). In March, however, there was a gradual increase in abundance with increasing distance from the waterline, with a peak at station $8(5,124$ ind. $10 \mathrm{~cm}^{-2}$ ). Lowest abundance was found at station 10 for 
Fig. 3 Multivariate analyses of community structure. a Cluster analyses based on Bray-Curtis similarities resulting in three main groups at $18.26 \%$ similarity in September 2007 and $18.25 \%$ in March 2008, indicated by the dotted lines. Symbols represent intertidal regions: open circles lower beach (September 2007 stations 1-3; March 2008 stations 1-3, 5, 7), asterisks middle beach (September 2007 stations 4-9; March 08 stations 4, 6, 8, 9), black squares upper beach (station 10). b Nonmetric multidimensional scaling (MDS) of genus abundance for both sampling seasons. Replicate samples are identified by their station number. Lines reflect the same three main groups that resulted from the cluster analyses: continuous line station 10 , dashed line stations 4-9 in September 2007 and stations 4, 6, 8, 9 in March 2008, dotted line stations 1-3 in September 2007 and stations 1-3, 5, 7 in March 2008. c Non-metric multidimensional scaling (MDS) of environmental variables (mean grain size, chlorophyll $a$ and organic matter). Replicate samples are identified by their station number
Sept. 07

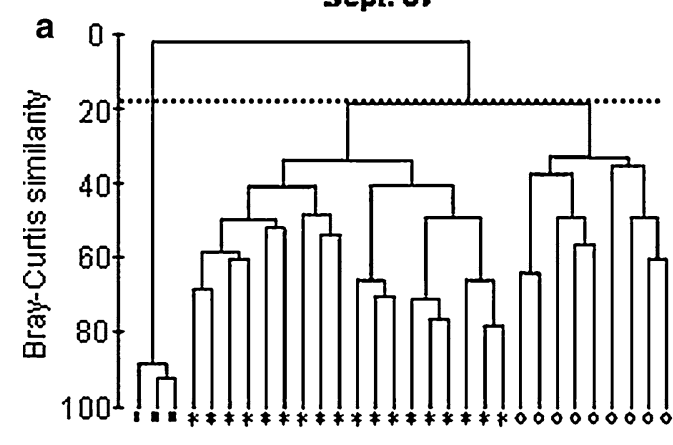

b

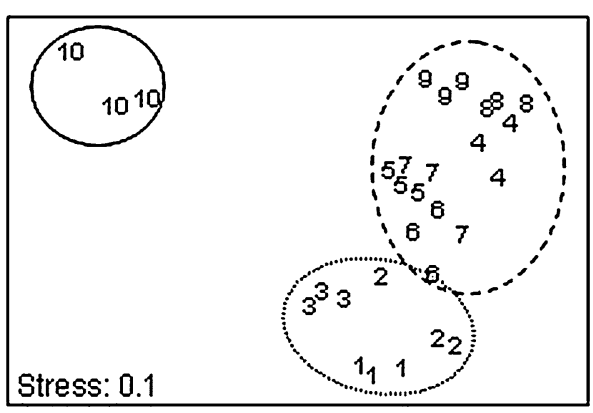

c

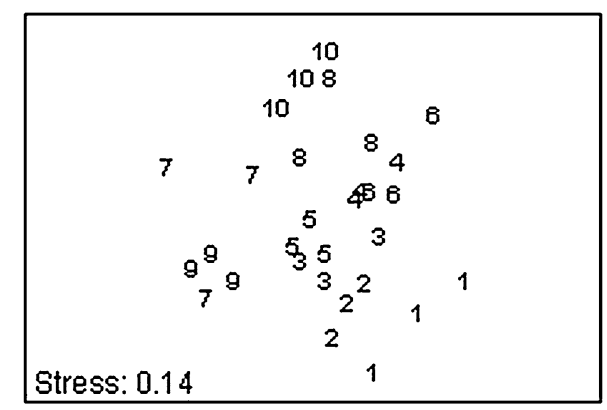

March 08
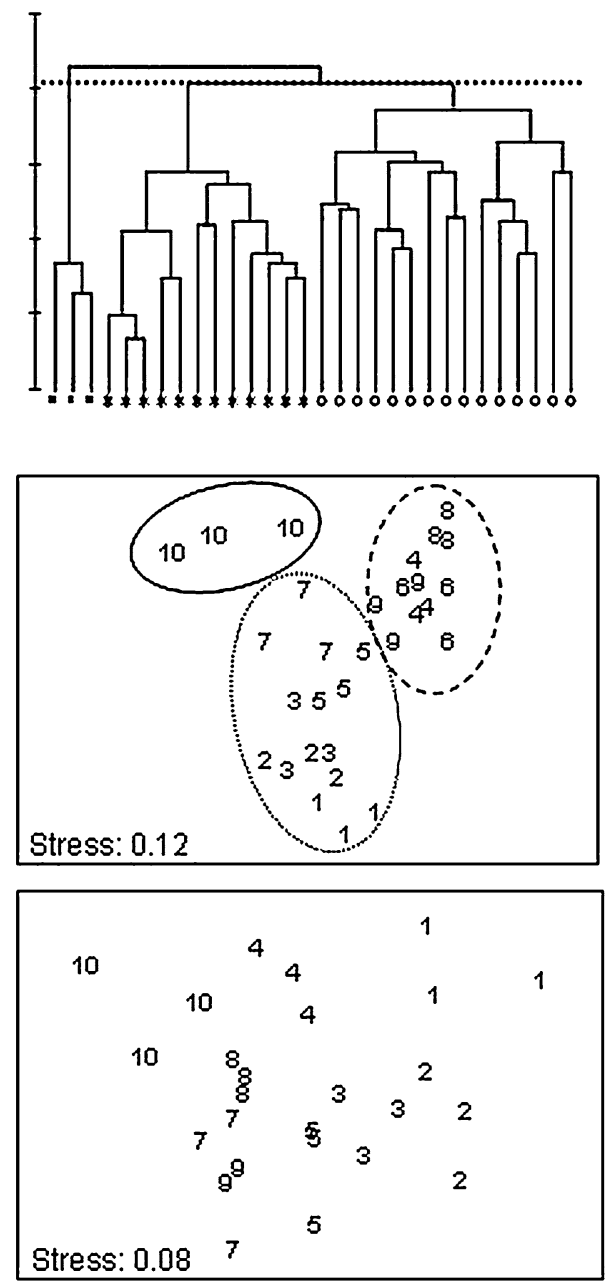

both seasons (September 2007: 277 ind. $10 \mathrm{~cm}^{-2}$; March 2008: 121 ind. $10 \mathrm{~cm}^{-2}$; Fig. 2e).

A total of 96 genera belonging to 25 families were recorded among 3,000 individuals (September 2007: 23 families and 74 genera; March 2008: 23 families and 87 genera; see supplementary material). Highest genus richness and diversity (Shannon Wiener $H^{\prime}$ ) occurred at station 1 [mean ( \pm SD); September 2007: 25.67 ( \pm 1.53$)$ genera, $H^{\prime}=2.99( \pm 0.12)$; March 2008: $26.67( \pm 2.31)$ genera, $\left.H^{\prime}=3.04( \pm 0.12)\right]$ followed by station 2 (September 2007: $21.67( \pm 2.52)$ genera, $H^{\prime}=2.8( \pm 0.19)$; March 2008: $22.67( \pm 3.21)$ genera, $H^{\prime}=2.85( \pm 0.2)$; Fig. 2f, g). A second peak in genus richness and diversity was found at station 6 in September $\left[23.67( \pm 3.21)\right.$ genera, $H^{\prime}=2.86$ $( \pm 0.21)]$ and station 7 in March [23.67 $( \pm 2.08)$ genera, $H^{\prime}=2.83$ ( \pm 0.22$)$; Fig. 2f, g).

Community structure of runnels and sandbars

Nematode assemblages from runnels were significantly different from sandbars (ANOSIM, September 2007:
$R=0.103, p=0.027$; March 2008: $R=0.228, p=0.01$ ). Accordingly, they differed in most community attributes: abundance was higher in runnels in September 2007 $(t=2.111, p=0.04)$ but not in March $2008(t=-0.78$, $p>0.2$; Fig. 2e). Higher taxonomic and functional diversities were found in runnels in both seasons (number of genera in runnels vs. sandbars: September 2007: 67 vs. 56, March 2008: 79 vs. 60; Genus richness $S$ : September 2007: $t=2.276, \quad p=0.03$; March 2008: $t=4.6, \quad p<0.0001$; Fig. 2f; Shannon Wiener $H^{\prime}$ : September 2007: $t=2.636$, $p<0.05$; March 08: $t=4.665, p<0.001$; Fig. 2 g; ITD $^{-1}$ : September 2007: $t=2.44, p<0.05$; March 2008: $t=3.49$, $p<0.01$; Fig. 2h). SIMPER analyses pointed in the same direction: in sandbars only two (March 2008) or three (September 2007) genera accounted for $50 \%$ of the cumulative similarity (Table 1), whereas in runnels there were at least twice as many (September 2007: 6; March 2008: 6, Table 1). In runnels, the discriminating genera revealed by SIMPER represented all four feeding groups, whereas in sandbars, there were only two, namely $2 \mathrm{~A}$ (epistrate feeders) and 1B (non-selective deposit feeders; Table 1). More 
Table 1 Percentage contribution of the top 50\% discriminating genera for each assemblage and their feeding strategy (FS)

\begin{tabular}{llll}
\hline & Genus & FS & $\begin{array}{l}\text { Cumulative } \\
\text { percentage }(\%)\end{array}$ \\
\hline RUNNEL & & & \\
September 2007 & Epsilonematidae gen. & 1A & 25.68 \\
& Xyala sp 2 & 1B & 33.17 \\
& Chromadorita & 2A & 38.94 \\
& Xyala sp 1 & 1B & 44.41 \\
& Richtersia & 1B & 49.08 \\
March 2008 & Metachromadora & 2B & 53.13 \\
& Xyalidae gen. & 1B & 15.73 \\
& Chromadorina & 2A & 25.30 \\
& Chromadorita & 2A & 34.31 \\
& Epsilonematidae gen. & 1A & 41.17 \\
& Pomponema & 2A & 46.37 \\
& Metachromadora & 2B & 51.15 \\
SANDBAR & & & \\
& Epsilonematidae gen. & 1A & 36.34 \\
& Praeacanthonchus & 2A & 44.98 \\
& Desmodora sp 1 & 2A & 50.94 \\
& Epsilonematidae gen. & 1A & 38.75 \\
& Chromadorina & 2A & 55.53 \\
\hline
\end{tabular}

than a fifth $(21.87 \%)$ of all genera were exclusive of runnels, whereas fewer genera were exclusive of sandbars $(8.3 \%)$.

Environmental variables had a significant influence on the structure of the nematode community, indicated by significant correlations between faunal and environmental variables (RELATE analysis: September 2007: $\rho=0.42$, $p=0.001$; March 2008: $\rho=0.464, p=0.001$ ). Accordingly, organic matter content was higher in runnels; however, the difference was significant only in September (2007: $t=2.785, \quad p=0.0095$; March 2008: $t=1.878$, $p=0.072$; Fig. 2c). Chlorophyll $a$ content was significantly higher in runnels in both seasons (September 2007: $t=3.749, p=0.0008$; March 2008: $t=3.133, p=0.004$; Fig. 2d). On the other hand, there was no significant difference in mean grain size between runnels and sandbars (September 2007: $t=-0.079, p=0.94$; March 2008: $t=0.344$, $p=0.73$; Fig. 2b).

Intertidal runnels possessed a different faunal composition from station 1, based on SIMPER analyses between station 1 and higher intertidal runnels. Station 1 is located at the transition line between the sub- and intertidal region. Higher intertidal runnels comprised a large number of genera that did not contribute to the similarity within station 1 (September 2007: 14/28 [50\%]; March 2008: 19/34 [56\%]). The contribution of the top discriminating genera for each runnel suggested a "dilution effect", in which typical nema-

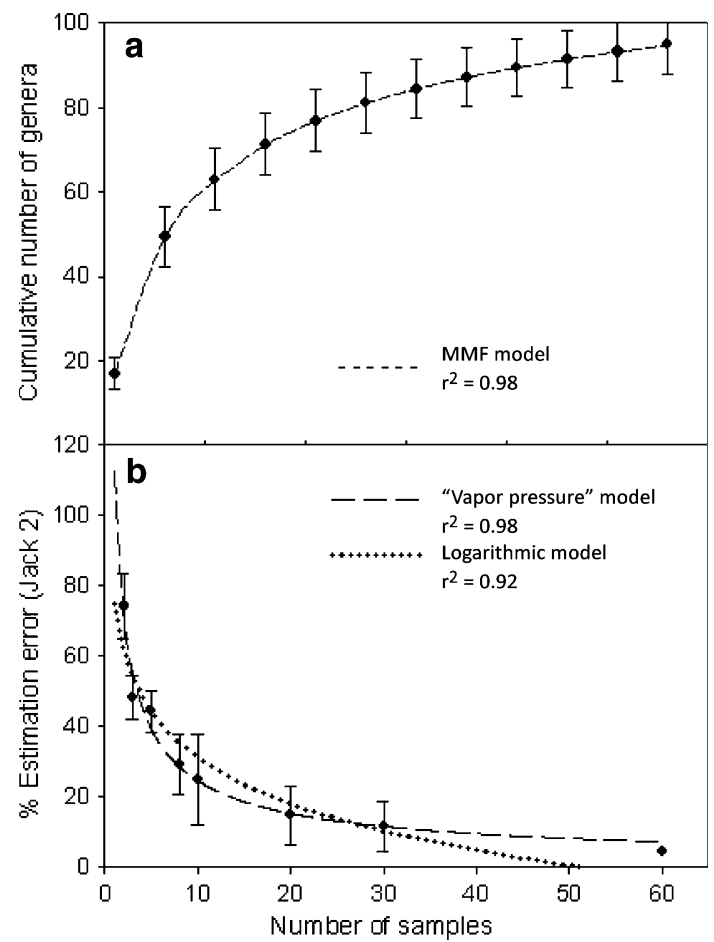

Fig. 4 Local diversity and error estimations. a Species accumulation curve using the Ugland index for the combined datasets of September 2007 and March 2008 (black diamonds). The line indicates the adjusted MMF Model $y=\left(a b+c x^{d}\right) /\left(b+x^{d}\right)$, where the model parameters are: $a=-7.97, b=4.36, c=125.03$ and $d=0.67$. b Relative estimation error (mean and standard deviation) of the second-order jacknife richness estimator (Jack 2) for different samplesizes (black circles). Adjusted models: logarithmic model $y=a+b \ln (x)$ with the model parameters: $a=74.91, b=-18.99$ (dotted line) and "vapor pressure model" $y=\mathrm{e}^{a+b x+c \ln x}$ with the model parameters: $a=4.78, b=-0.05$ and $c=-0.68$ (dashed line). $r^{2}$ coefficient of determination

todes of station 1 were replaced by new taxa toward the higher beach. This is reflected in the higher dissimilarity values of runnels relative to station 1 with increasing distance from the sea (Table 2).

Local and regional diversity estimations

Based on data from both sampling seasons, the estimated asymptotic number of genera was 125 (MMF model adjusted to the SAC, $r^{2}=0.98$; Fig. 4a). Non-parametric estimations yielded maxima of 106 (ICE) and 120 genera (Jack 2), with an estimated error of $4.3 \%$ with 60 samples for the latter (Fig. 4b). Of the two models tested, the so-called "vapor pressure model" gave a better fit $\left(y=\mathrm{e}^{a+b x+c \ln x}\right.$, $\left.r^{2}=0.98\right)$ than the logarithmic $\left(y=a+b \ln (x), r^{2}=0.92\right)$. Error estimates ranged from zero with 52 samples, for the latter, and $7.3 \%$ with 60 and $<5 \%$ with 104 samples, for the former (Fig. 4b).

The ICE and the observed number of genera were approximately $1.5-1.7$ times higher in El Tornillal 
Table 2 Presence of the top 90\% discriminating genera across the intertidal

\begin{tabular}{|c|c|c|c|c|c|}
\hline & Station 1 & Runnel 3 & Runnel 5 & Runnel 7 & Runnel 9 \\
\hline \multicolumn{6}{|l|}{ September 2007} \\
\hline Dissimilarity & - & 66.67 & 77.11 & 82 & 95.33 \\
\hline \multirow[t]{14}{*}{ Station 1} & Marylynnia & & & & \\
\hline & Cobbia & $X$ & & & \\
\hline & Pomponema & & $X$ & & \\
\hline & Dichromadora & $X$ & & $X$ & \\
\hline & Chromadorita & $\mathrm{X}$ & & $\mathrm{X}$ & \\
\hline & Actinonema & & & & \\
\hline & Ceramonema sp 2 & & $X$ & & \\
\hline & Xyalidae Gen. & & & & \\
\hline & Nannolaimoides & & & & \\
\hline & Richtersia & $X$ & & $X$ & \\
\hline & Latronema & & & & \\
\hline & Paracomesoma & & & & \\
\hline & Xyala $\mathrm{sp} 2$ & $X$ & $X$ & $X$ & \\
\hline & Catanema sp 1 & & $\mathrm{X}$ & & \\
\hline \multirow[t]{14}{*}{ New } & & Desmodora sp 1 & $\mathrm{X}$ & & \\
\hline & & Tricoma & $\mathrm{X}$ & $X$ & \\
\hline & & Xyala sp 1 & $\mathrm{X}$ & & \\
\hline & & Rhynchonema & $\mathrm{X}$ & $X$ & \\
\hline & & & Epsilonematidae gen. & $X$ & $X$ \\
\hline & & & Metachromadora & $\mathrm{X}$ & \\
\hline & & & Oncholaimidae Gen. & $\mathrm{X}$ & \\
\hline & & & & Desmodora sp 2 & $X$ \\
\hline & & & & Chromaspirinia & \\
\hline & & & & Ceramonema sp 3 & \\
\hline & & & & Enoploides & \\
\hline & & & & Gammanema & $\mathrm{X}$ \\
\hline & & & & & Theristus sp 2 \\
\hline & & & & & Microlaimus sp 2 \\
\hline \multicolumn{6}{|l|}{ March 2008} \\
\hline Dissimilarity & - & 63.66 & 75.85 & 85.37 & 86.26 \\
\hline \multirow[t]{15}{*}{ Station 1} & Pomponema sp 1 & $\mathrm{X}$ & $\mathrm{X}$ & & \\
\hline & Xyalidae Gen. & $\mathrm{X}$ & $\mathrm{X}$ & & $\mathrm{X}$ \\
\hline & Cobbia & $\mathrm{X}$ & & & \\
\hline & Dichromadora & & & & \\
\hline & Marylynnia & $X$ & & & \\
\hline & Promonhystera & & & & \\
\hline & Ceramonema sp 2 & & & & \\
\hline & Daptonema & $\mathrm{X}$ & & & \\
\hline & Cyartonema & & & & \\
\hline & Nannolaimoides & & & & \\
\hline & Pomponema sp 2 & & & & \\
\hline & Stylotheristus & & & & \\
\hline & Prochromadorella & & $X$ & $X$ & \\
\hline & Richtersia & $X$ & & $X$ & \\
\hline & Viscosia & & & & \\
\hline
\end{tabular}


Table 2 continued

\begin{tabular}{|c|c|c|c|c|c|}
\hline & Station 1 & Runnel 3 & Runnel 5 & Runnel 7 & Runnel 9 \\
\hline \multirow[t]{19}{*}{ New } & & Chromadorita & $\mathrm{X}$ & $\mathrm{X}$ & \\
\hline & & Xyala sp 1 & & & \\
\hline & & Metachromadora & $X$ & $\mathrm{X}$ & \\
\hline & & Desmodora sp 1 & & & $X$ \\
\hline & & & Chromadorina & $\mathrm{X}$ & $\mathrm{X}$ \\
\hline & & & Epsilonematidae gen. & $\mathrm{X}$ & $\mathrm{X}$ \\
\hline & & & Odontophora & $X$ & \\
\hline & & & Tricoma & $\mathrm{X}$ & $\mathrm{X}$ \\
\hline & & & Enoploides & & $X$ \\
\hline & & & Neochromadora & & \\
\hline & & & & Chromaspirinia & \\
\hline & & & & Epacanthion & \\
\hline & & & & Chromadoridae gen. & \\
\hline & & & & Rhynchonema & \\
\hline & & & & & Microlaimus sp 2 \\
\hline & & & & & Xyala sp 1 \\
\hline & & & & & Theristus $\mathrm{sp} 2$ \\
\hline & & & & & Metoncholaimus \\
\hline & & & & & Oxyonchus \\
\hline
\end{tabular}

Dissimilarity result from SIMPER analyses between station 1 and the respective runnel, $X$ contributing genus that has been listed before, New appearance of a new discriminating genus

$(\mathrm{ICE}=106$ for a total of 96 observed genera) than in Santa Clara Beach (ICE $=72$ for a total of 55 observed genera), a homogeneous beach located $25 \mathrm{~km}$ north from our study site (Mundo-Ocampo et al. 2007). At Santa Clara, sampling involved a $30 \times 60-\mathrm{m}$ grid at the low intertidal and the number of identified nematodes was ca. 600. Given the different sampling efforts, comparison of that study with the lower intertidal of El Tornillal, i.e. stations 1, 2, and 3, is more meaningful. Genus richness at Santa Clara beach was 55 (Mundo-Ocampo et al. 2007) and at the lower intertidal of El Tornillal 73. The two combined host a total of 87 genera, with almost half of them being shared (41/87). More than one-third (32/87) were found exclusively at the structurally complex El Tornillal beach, whereas only less than half of that (14/87) were unique to the feature-less beach at Santa Clara.

\section{Discussion}

Intertidal three-tiered zonation dominates over structural complexity

One of the goals of this study was to test whether meiofaunal intertidal cross-shore distribution patterns were dominant over structural complexity. To our knowledge, the influence of topographical heterogeneity in the structure of a nematofaunal community has never been addressed. In many beaches, three different assemblages have been discerned (Gheskiere et al. 2005; Rodriguez 2004). Gheskiere et al. (2004) found that the nematofaunal zonation of a topographically comparable beach (De Panne, Belgium) involved three assemblages across the intertidal, with a fourth, distinct assemblage at the driftline. However, sampling was restricted to sandbars, since the authors hypothesized that meiofauna in runnels consisted mostly of subtidal organisms. Consequently, the effect of runnels on intertidal zonation patterns remained unexplored. Our results show that the presence of topographical complexity, in the form of runnels and sandbars, did not alter the expected zonation pattern involving three major assemblages of nematodes. At El Tornillal, these assemblages correlated with changes in chlorophyll $a$ and mean grain size.

The nematode assemblage in the uppermost limit of the intertidal zone (station 10) was consistently unique and survived in very low to undetectable chlorophyll $a$ levels. Juvenile Praeacanthonchus accounted for $82 \%$ of nematodes and were exclusive of this station in September, whereas adult Praeacanthonchus appeared in the middle intertidal 6 months later, at which time Trichotheristus dominated the community at station 10 . As adults, Praeacanthonchus are herbivores (Moens et al. 2005), and their high abundance at station 10 in September is surprising given the low chlorophyll $a$ levels. Furthermore, osmotic 
and temperature stress may reach levels limiting survival, reproduction, and maturation time as well as assimilation and respiration (Moens and Vincx 2000a, b). Given the extreme environmental conditions at station 10, other advantages may be responsible for enhanced juvenile survival rates, such as low intra- and interspecific competition due to decreased nematode abundance and diversity.

The rest of the intertidal community was grouped in two assemblages associated with different mean grain sizes, reflecting the gradient of tidal and wave energy across shore. Grain size is an important factor structuring nematode communities (Gheskiere et al. 2004, 2005), given their interstitial abode during their entire life cycle. The zonation pattern at El Tornillal was temporally variable. In September, lower (station 1-3) and middle (station 4-9) nematode assemblages were clear-cut and did not overlap. In March, nematodes from middle runnels (stations 5 and 7) clustered with those from the lower intertidal (stations 1-3), reflecting a greater biological similarity presumably favored by enhanced passive transport induced by stronger wave action and hibernal winds (Lluch-Cota et al. 2007).

The existence of specific taxa characteristic of particular intertidal levels is better documented in macrofauna (McLachlan and Jaramillo 1995) than in meiofauna. The fact that some nematode genera consistently dominated certain intertidal horizons in contrasting seasons suggests that a substantial part of the community may be spatially constrained to complete their life cycles. Gheskiere et al. (2005) hypothesized the existence of isocommunities to refer to specific species assemblages resulting from community convergence at given intertidal levels among geographically separated beaches with similar morphodynamics. Comparison of our typical genera in each intertidal level with their analogs at De Panne does not support the isocommunity hypothesis. At El Tornillal, Pomponema, Marylynnia, and Cobbia were among the top five discriminating genera in the lower beach in both seasons, whereas Epsilonema, Microlaimus, and Tricoma were the same in the middle beach. These genera differ from those discriminating at De Panne (Gheskiere et al. 2004).

Across-shore abundance and diversity patterns are consistent with IDH and DEH

Meiofaunal abundance patterns are spatially and temporally heterogeneous in the intertidal, but many studies have documented a peak in meiobenthic diversity around the mid-intertidal of sandy beaches in response to intermediate disturbance levels (Armonies and Reise 2000; Gheskiere et al. 2004). Although the abundance pattern at El Tornillal was not temporally consistent, the existence of two diversity peaks at different intertidal levels at our study site points to the presence of two environmental optima, which may relate to the interaction of different mechanisms (IDH and DEH).

Mean nematode abundances at El Tornillal and Santa Clara were of comparable magnitude (Mundo-Ocampo et al. 2007) and fall within the range of other studies (Gheskiere et al. 2004; Rodriguez et al. 2001). At El Tornillal, abundance peaked at the middle beach (station 7 in September 3,247 ind. $10 \mathrm{~cm}^{-2}$ and station 8 in March 5,124 ind. $10 \mathrm{~cm}^{-2}$ ), whereas in the morphodynamically similar macrotidal beach at De Panne highest abundance occurred at the lower beach $\left(2,784\right.$ ind. $\left.10 \mathrm{~cm}^{-2}\right)$. A pattern of increasing meiofaunal abundance with increasing distance from the sea has been reported for many beaches (Gheskiere et al. 2005; Nicholas and Hodda 1999; Rodriguez et al. 2001).

At El Tornillal, a peak in genus richness occurred in the mid-intertidal, in concert with the pattern described in other studies (Armonies and Reise 2000; Gheskiere et al. 2004). According to the IDH, intermediate disturbance allows for the coexistence of more species because, on the one hand, it mediates periodic reductions of competitive dominant species precluding competitive exclusion, and on the other, disturbance is not as extreme as to reset ecological succession in favor of opportunistic and competitively inferior $r$-selected species (Huston 1979). Intermediate levels of disturbance in the middle beach result from gradients of disturbance produced by surf and swash processes and aerial exposure. At El Tornillal, sediment mean grain size indicates a cross-shore gradient of hydrodynamic energy, indicating that disturbance levels at the mid-intertidal intermediate. Also, desiccation due to tidal exposure and related temperature fluctuations are intermediate. These factors create a more extreme environment in the upper intertidal (high desiccation and temperature fluctuation) and more stable conditions in the lower intertidal (predominantly submerged, thus experiencing moderate temperature fluctuations). The high intertidal (station 10) is characterized by consistent low diversity levels. Intermediate levels of disturbance are thus reasonable explanations for the mid-intertidal peak in species richness.

The lower intertidal limit (station 1), exhibited a second peak and overall maximum in genus richness, which suggests the existence of another set of optimal conditions favoring diversity. Given the different processes prevailing in the lower intertidal, this optimum likely involves other factors than those responsible for the middle intertidal peak. The DEH predicts maximum species richness under conditions of intermediate productivity and disturbance, since high productivity promotes a positive relationship between diversity and disturbance whereas low productivity reverses it (Huston 1994). Intermediate productivity in the lower intertidal is suggested by the levels of organic matter and chlorophyll $a$ (Fig. 2c, d). Macrofauna and megafauna 
may act as sources of intermediate disturbance; since high macrofaunal species richness and abundance generally occur in the lower intertidal of sandy beaches as is also the case in the UGC (Avila-Serrano et al. 2006; McLachlan and Jaramillo 1995). Macrofauna may affect meiofaunal community structure through complex interactions involving predation and bioturbation (Austen et al. 1998). In addition, wading birds congregate close to the waterline to roost and feed, disturbing superficial sediments (personal observations). Moreover, excreta and feces from birds may be a source of organic matter to the infaunal community (Palomo et al. 1999). Finally, the maximum in species richness found at the limit between the sub- and intertidal also reflects the transitional nature of this zone.

\section{Intertidal runnels harbor distinct communities}

augmenting regional diversity estimates

A major contribution of this study is the comparative analysis of the nematofauna from two microhabitats (intertidal runnels and sandbars). Former studies have limited their scope to analyzing the influence of environmental factors on the structure of meiofaunal communities, largely neglecting the role of habitat heterogeneity. Our results revealed major differences in environmental parameters and in the nematofauna inhabiting intertidal runnels and sandbars. Chlorophyll $a$ and organic matter levels revealed contrasting availability of food sources between them. Both were consistently and significantly higher in runnels (except for the organic matter in winter), presumably owing to the presence of conspicuous benthic algal mats, as well as detritus and microbial biomass. Runnels and sandbars represent thus microhabitats with contrasting environmental conditions and distinct resource provisions.

Previous studies assumed that nematodes found in runnels represent a subset of subtidal fauna (Gheskiere et al. 2004). According to this, we would have expected that runnels host a fraction of the genera found at station 1 , which was located at the transition to the subtidal. However, the runnels did not represent a subset of station 1 but a distinct community from it. Its distinctiveness was best reflected by the dilution of taxa typical for station 1 away from the sea and concomitant increase in the number of runnelrestricted genera. More than a fifth of the overall taxonomic richness (21 genera out of 96) was exclusive for runnels, and they would have been missed had we only focused on sandbars. This high number (21) of genera unique to runnels was more than double that of sandbar-specific genera (8). The high taxonomic diversity may be due to the relatively high hydrodynamic stability provided by being sheltered from cross-shore currents and by superficial sediment cohesion produced by phytobenthic algal films (Sutherland et al. 1998). This allows nematodes to control their spatial distribution by actively selecting their environment (Ullberg and Olafsson 2003), burrowing and attaching themselves to sediment particles (Chandler and Fleeger 1983). Not only taxonomic, but also functional diversity was higher in runnels, where the top $50 \%$ of discriminating genera represented all feeding groups, indicating that they provide resources for herbivores, bacterivores, organic matter users, as well as predators. On the other hand, only genera from feeding groups $1 \mathrm{~A}$ (selective deposit feeders) and $2 \mathrm{~A}$ (epistrate feeders) were among the major taxa in sandbars. The relative stability of the runnel environment, and the high abundance of microphytobenthos and organic matter may promote favorable conditions for the coexistence of more functional groups.

Our study highlights the importance of habitat heterogeneity in determining nematofaunal community structure and diversity in the intertidal. This stands in line with the $\mathrm{HHH}$ and many other studies reporting on the importance of habitat heterogeneity for diversity (O'Dea et al. 2006; Tews et al. 2004). Comparison of the lower intertidal of a structurally heterogeneous (El Tornillal) with a nearby featureless beach (Santa Clara Beach) revealed that $33 \%$ of the regional taxon richness was unique to the former, whereas only $16 \%$ was restricted to the latter. The high taxon turnover between sites (only $47 \%$ of the genera were shared) may be unexpected, given the proximity of the beaches and the potential for passive transport. It suggests a high level of regional diversity on the east coast of the UGC. More reliable estimates of regional taxon richness can be achieved by an approach that integrates extrapolation to a bigger area in the presence of habitat heterogeneity. Ugland et al. (2003) proposed a Total-Species Curve (T-S) constructed by joining the endpoints of SACs constructed for each different habitat. The T-S can then be extrapolated to a bigger area and usually yields much higher estimates than non-parametric estimators (Ugland et al. 2003). Many beaches along the coasts of the UGC are heterogeneous featuring microhabitats such as the ones described here (sandbars and runnels), but also rocky outcrops, vegetation, freshwater inputs and others. Our results point to the need for a thorough survey of these habitats in the UGC, a region where the marine nematofauna has only begun to be described (Holovachov et al. 2008a, b, 2009), and for the use of improved models to estimate regional species richness.

Acknowledgments We are very thankful to Renato Salvatteci and Martín Julián Estara Parada for their valuable and vital help in the field. We gratefully acknowledge Tom Moens, Sharon Herzka, Melissa Yoder, Beat von Siebenthal, Silvia Ibarra, Renato Salvatteci and two anonymous referees for constructive discussions and suggestions to earlier versions of this manuscript. R.G. thanks Paul Somerfield for the excellent instruction on the use of PRIMER during the SFO workshop. This research was funded by the grant CONACYT-SEMARNAT2004-C01-300 to ARO. The paper derived from the first author's Ph.D. research at the Marine Ecology program at CICESE where she is 
supported by CONACYT. Samples were collected under permit No. DGOPA. 05335.100707.2458 (SAGARPA).

Open Access This article is distributed under the terms of the Creative Commons Attribution Noncommercial License which permits any noncommercial use, distribution, and reproduction in any medium, provided the original author(s) and source are credited.

\section{References}

Anthony EJ, Levoy F, Monfort O, Degryse-Kulkarni C (2005) Shortterm intertidal bar mobility on a ridge-and-runnel beach, Merlimont, northern France. Earth Surf Proc Land 30:81-93

Armonies W, Reise K (2000) Faunal diversity across a sandy shore. Mar Ecol Prog Ser 196:49-57

Aronson RB, Precht WF (1995) Landscape patterns of reef coral diversity: a test of the intermediate disturbance hypothesis. J Exp Mar Biol Ecol 192:1-14

Austen MC, Widdicombe S, Villano-Pitacco N (1998) Effects of biological disturbance on diversity and structure of meiobenthic communities. Mar Ecol Prog Ser 174:233-246

Avila-Serrano GA, Flessa KW, Téllez-Duarte MA, Cintra Buenrostro CE (2006) Distribución de la macrofauna intermareal del delta del río Colorado, Norte del Golfo de California, México. Cienc Mar 32:649-661

Bale AJ, Kenny AJ (2005) Sediment analysis and seabed characterization. In: Eleftheriou A, McIntyre A (eds) Methods for the study of marine benthos. Blackwell Science Ltd, Oxford, pp 43-86

Burnham KP, Overton WS (1979) Robust estimation of population size when capture probabilites vary among animals. Ecology 60:927-936

Canning-Clode J, Valdivia N, Molis M, Thomason JC, Wahl M (2008) Estimation of regional richness in marine benthic communities: quantifying the error. Limnol Oceanogr Methods 6:580-590

Chandler GT, Fleeger JW (1983) Meiofaunal colonization of azoic estuarine sediment in Louisiana: mechanisms of dispersal. J Exp Mar Biol Ecol 69:175-188

Chazdon RL, Colwell RK, Denslow JS, Guariguata MR (1998) Statistical methods for estimating species richness of woody regeneration in primary and secondary rain forest of northeastern Costa Rica. In: Dallmeier F, Comiskey JA (eds) Forest biodiversity research, monitoring and modelling. Smithsonian Institution, Washington

Clarke KR, Gorley RN (2001) PRIMER v6 PRIMER-E Ltd. Plymouth, $\mathrm{UK}$

Clarke KR, Warwick RM (1994) Change in marine communities: an approach to Statistical analysis and interpretation. Plymouth Marine Laboratory, Plymouth

Clarke KR, Somerfield PJ, Gorley RN (2008) Testing of null hypotheses in exploratory community analyses: similarity profiles and biota-environment linkage. J Exp Mar Biol Ecol 366:56-69

Colijn F, Dijkema KS (1981) Species composition of benthic diatoms and distribution of chlorophyll $a$ on an intertidal flat in the Dutch Wadden Sea. Mar Ecol Prog Ser 4:9-21

Colwell RK (2005) EstimateS: statistical estimation of species richness and shared species from samples. Version 7.5. http://purl.oclc. org/estimates

Cramer MJ, Willig MR (2005) Habitat heterogeneity, species diversity and null models. Oikos 108:209-218

Davidowitz G, Rosenzweig ML (1998) The latitudinal gradient of species diversity among North American grasshoppers (Acrididae) within a single habitat: a test of the spatial heterogeneity hypothesis. J Biogeogr 25:553-560
De Jonge VN, Bouwman LA (1977) A simple density separation technique for quantitative isolation of meiobenthos using the colloidal silica Ludox-TM. Mar Biol 42:143-148

Dean WEJ (1974) Determination of carbonate and organic matter in calcareous sediments and sedimentary rocks by loss of ignition: comparison with other methods. J Sed Petrol 44:242-248

Enríquez-Andrade R, Anaya-Reyna G, Barrera-Guevara JC, CarvajalMoreno MA, Martínez-Delgado ME, Vaca-Rodríguez J, ValdésCasillas C (2005) An analysis of critical areas for biodiversity conservation in the Gulf of California Region. Ocean Coast Manag 48:31-50

Flöder S, Sommer U (1999) Diversity in planktonic communities: an experimental test of the intermediate disturbance hypothesis. Limnol Oceanogr 44:1114-1119

French DD, Picozzi N (2002) 'Functional groups' of bird species, biodiversity and landscapes in Scotland. J Biogeogr 29:231-259

Froelich PN (1980) Analysis of organic carbon in marine sediments. Limnol Oceanogr 25:564-572

Gheskiere T, Hoste E, Vanaverbeke J, Vincx M, Degraer S (2004) Horizontal zonation patterns and feeding structure of marine nematode assemblages on a macrotidal, ultra-dissipative sandy beach (De Panne, Belgium). J Sea Res 52:211-226

Gheskiere T, Vincx M, Urban-Malinga B, Rossano C, Scapini F, Degraer S (2005) Nematodes from wave-dominated sandy beaches: diversity, zonation patterns and testing of the isocommunities concept. Estuar Coast Shelf Sci 62:365-375

Heip C, Vincx M, Vranken G (1985) The ecology of marine nematodes. Oceanogr Mar Biol 23:399-489

Hendrickx F, Maelfait JP, Van Wingerden W, Schweiger O, Speelmans M, Aviron S, Augenstein I, Billeter R, Bailey D, Bukacek R, Burel F, Diekotter T, Dirksen J, Herzog F, Liira J, Roubalova M, Vandomme V, Bugter R (2007) How landscape structure, land-use intensity and habitat diversity affect components of total arthropod diversity in agricultural landscapes. J Appl Ecol $44: 340-351$

Holovachov O, De Ley IT, Mundo-Ocampo M, Baldwin JG, RochaOlivares A, De Ley P (2008a) Nematodes from the Gulf of California. Part 1. The genera Ceramonema Cobb, 1920, Pselionema Cobb in Cobb, 1933 and Pterygonema Gerlach, 1954 (Nematoda: Ceramonematidae). Nematology 10:347-373

Holovachov O, Mundo-Ocampo M, De Ley IT, De Ley P (2008b) Nematodes from the Gulf of California. Part 2. Ceramonema nasobema sp n. (Nematoda: Ceramonematidae). Nematology 10:835-844

Holovachov O, De Ley IT, Mundo-Ocampo M, Gingold R, De Ley P (2009) Nematodes from the Gulf of California. Part 3. Three new species of the genus Diplopeltoides Gerlach, 1962 (Nematoda: Diplopeltoididae) with overviews of the genera Diplopeltis Gerlach, 1962 and Diplopeltula Gerlach, 1950. Russ J Nematol $17: 43-56$

Huston M (1979) A general hypothesis of species diversity. Am Nat 113:81-101

Huston MA (1994) Biological diversity: the coexistence of species on changing landscapes. Cambridge University Press, Cambridge

Huxham M, Roberts I, Bremner J (2000) A field test of the Intermediate Disturbance Hypothesis in the soft-bottom intertidal. Int Rev Hydrobiol 85:379-394

Kerr JT, Packer L (1997) Habitat heterogeneity as a determinant of mammal species richness in high-energy regions. Nature 385:252-254

King CAM (1972) Beaches and coasts. Edward Arnold, London

Lambshead PJD (1993) Recent development in marine benthic biodiversity research. Oceanis 19:5-24

Lluch-Cota SE, Aragon-Noriega EA, Arreguin-Sanchez F, AuriolesGamboa D, Bautista-Romero JJ, Brusca RC, Cervantes-Duarte R, Cortes-Altamirano R, Del-Monte-Luna P, Esquivel-Herrera A, Fernandez G, Hendrickx ME, Hernandez-Vazquez S, Herrera- 
Cervantes H, Kahru M, Lavin M, Lluch-Belda D, Lluch-Cota DB, Lopez-Martinez J, Marinone SG, Nevarez-Martinez MO, Ortega-Garcia S, Palacios-Castro E, Pares-Sierra A, Ponce-Diaz G, Ramirez-Rodriguez M, Salinas-Zavala CA, Schwartzlose RA, Sierra-Beltran AP (2007) The Gulf of California: review of ecosystem status and sustainability challenges. Prog Oceanogr 73:1-26

Lorenzen CJ (1967) Determination of chlorophyll and pheo-pigments: spectrophotometric equations. Limnol Oceanogr 12:343-346

MacArthur R, Wilson OE (1967) The theory of island biogeography. Princeton University Press, Princeton

Masselink G, Short AD (1993) The effect of tide range on beach morphodynamics and morphology: a conceptual beach model. J Coast Res 9:785-800

Masselink G, Kroon A, Davidson-Arnott RGD (2006) Morphodynamics of intertidal bars in wave-dominated coastal settings: a review. Geomorphology 73:33-49

McLachlan A, Brown AC (2006) The ecology of sandy shores. Academic Press, Elsevier

McLachlan A, Jaramillo E (1995) Zonation on sandy beaches. Oceanogr Mar Biol 33:305-335

McLachlan A, Turner I (1994) The interstitial environment of sandy beaches. Mar Ecol Pubbl Stn Zool Napoli 15:177-211

Moens T, Vincx M (2000a) Temperature and salinity constraints on the life cycle of two brackish-water nematode species. J Exp Mar Biol Ecol 243:115-135

Moens T, Vincx M (2000b) Temperature, salinity and food thresholds in two brackish-water bacterivorous nematode species: assessing niches from food absorption and respiration experiments. J Exp Mar Biol Ecol 243:137-154

Moens T, Bouillon S, Gallucci F (2005) Dual stable isotope abundances unravel trophic position of estuarine nematodes. J Mar Biol Assoc UK 85:1401-1407

Morgan PH, Mercer LP, Flodin NW (1975) General model for nutritional responses of higher organisms. Proc Natl Acad Sci USA 72:4327-4331

Mundo-Ocampo M, Lambshead PJD, Debenham N, King IW, De Ley P, Baldwin JG, De Ley IT, Rocha-Olivares A, Waumann D, Thomas WK, Packer M, Boucher G (2007) Biodiversity of littoral nematodes from two sites in the Gulf of California. Hydrobiologia 586:179-189

Nicholas WL, Hodda M (1999) The free-living nematodes of a temperate, high energy, sandy beach: faunal composition and variation over space and time. Hydrobiologia 394:113-127
O’Dea N, Whittaker RJ, Ugland KI (2006) Using spatial heterogeneity to extrapolate species richness: a new method tested on Ecuadorian cloud forest birds. Ecology 43:189-198

Palomo G, Iribarne O, Martinez MM (1999) The effect of migratory seabirds guano on the soft bottom community of a SW Atlantic coastal lagoon. Bull Mar Sci 65:119-128

Platt HM, Warwick RM (1983) Freeliving marine nematodes: Part I. British Enoplids. Cambridge University Press, Cambridge

Platt HM, Warwick RM (1988) Freeliving marine nematodes: Part II. British Chromadorida. Brill, Leiden

Rodil IF, Lastra M, Sanchez-Mata AG (2006) Community structure and intertidal zonation of the macroinfauna in intermediate sandy beaches in temperate latitudes: north coast of Spain. Estuar Coast Shelf Sci 67:267-279

Rodriguez JG (2004) Community structure of intertidal meiofauna along a gradient of morphodynamic states on an exposed North Sea beach. Sarsia 89:22-23

Rodriguez JG, Lopez J, Jaramillo E (2001) Community structure of the intertidal meiofauna along a gradient of morphodynamic sandy beach types in southern Chile. Rev Chil Hist Nat 74:885-897

Sokal RR, Rohlf FJ (1995) Biometry the principles and practice of statistics in biological research. W.H. Freeman and Company, New York

Statsoft (2005) STATISTICA (data analysis software system), v7.1. Statsoft Inc. http://www.statsoft.com

Sutherland TF, Grant J, Amos CL (1998) The effect of carbohydrate production by the diatom Nitzschia curvilineata on the erodibility of sediment. Limnol Oceanogr 43:65-72

Tews J, Brose U, Grimm V, Tielborger K, Wichmann MC, Schwager M, Jeltsch F (2004) Animal species diversity driven by habitat heterogeneity/diversity: the importance of keystone structures. J Biogeogr 31:79-92

Ugland KI, Gray JS, Ellingsen KE (2003) The species-accumulation curve and estimation of species richness. J Anim Ecol 72:888-897

Ullberg J, Olafsson E (2003) Free-living marine nematodes actively choose habitat when descending from the water column. Mar Ecol Prog Ser 260:141-149

Warwick RM, Platt HM, Somerfield PJ (1998) Free-living marine nematodes Part III: Monhysterids. Synopses of the British fauna (new series). Field studies council, Shrewsbury

Wieser W (1953) Die Beziehung zwischen Mundhöhlengestalt, Ernährungsweise und Vorkommen bei freilebenden marinen Nematoden. Arkiv för Zoologi 4:439-484

Zar JH (1984) Biostatistical analysis. Prentice Hall, Englewood Cliffs 